\title{
Occurrence of Kellicottia bostoniensis (Rousselet, 1908) and Mesocyclops ogunnus Onabamiro, 1957 in lakes of the Middle River Doce, MG, Brazil
}

\author{
Ocorrência de Kellicottia bostoniensis (Rousselet, 1908) e Mesocyclops ogunnus
} Onabamiro, 1957 em lagos do Médio Rio Doce, MG

Raul Soares Peixoto, Luciana Pena Mello Brandão,

Carla de Fátima Valadares and Paulina Maria Maia Barbosa

\begin{abstract}
Laboratório de Ecologia do Zooplâncton, Universidade Federal de Minas Gerais- UFMG, Av. Antônio Carlos, 6627, Pampulha, CP 486, CEP 31270-901, Belo Horizonte, MG, Brazil e-mail: raulspeixoto@yahoo.com.br, lucianapmb@hotmail.com, cfvaladares@yahoo.com.br, maia@icb.ufmg.br
\end{abstract}

\begin{abstract}
The presence of the two exotic zooplankton species (Kellicottia bostoniensis and Mesocyclops ogunnus) in lakes of the Middle River Doce is discussed in the present work. K. bostoniensis was registered in Lakes Jacaré, Carioca and Águas Claras while M. ogunnus was restricted to the littoral zone of Lake Dom Helvécio. These zooplankton species may have been introduced in these environments by human action. Despite the low densities registered for both species, the monitoring of the invasion process is necessary to evaluate possible impacts on the zooplankton community structure in the lakes of Middle River Doce.
\end{abstract}

Keywords: exotic species, Copepoda, Rotifera, Kellicottia bostoniensis, Mesocyclops ogunnus.

Resumo: A presença de duas espécies zooplanctônicas exóticas (Kellicottia bostoniensis e Mesocyclops ogunnus) em lagos do Médio Rio Doce é discutida no presente trabalho. K. bostoniensis foi registrada nas lagoas Jacaré, Carioca e Águas Claras, enquanto M. ogunnus esteve restrita a região litorânea do Lago Dom Helvécio. Estas espécies zooplanctônicas podem ter sido introduzidas nestes ambientes pela ação antrópica. Apesar das baixas densidades observadas para as duas espécies, o monitoramento do processo de invasão é necessário para avaliar os possíveis impactos sobre a estruturação da comunidade zooplanctônica nos lagos do Médio Rio Doce.

Palavras-chave: espécies exóticas, Copepoda, Rotifera, Kellicottia bostoniensis, Mesocyclops ogunnus.

The invasion of communities by exotic species is a concern not only to the academic and scientific communities, but has also alarmed different segments of society, since this phenomenon has dramatically increased worldwide (Mooney and Hobbs, 2000). The deployment of transport on a global scale over the past four centuries, together with the lack of control and the characteristic speed of these processes meant that species previously isolated by geographic barriers were able to overcome these obstacles and establish themselves in new regions (Ricciardi and Maclssac, 2000).

Once introduced, the species can successfully establish itself at the new environment and, eventually, become an invasive species, disrupting the composition of the local community (Williamson, 1996). Currently, the introduction of exotic species is considered the second major cause of loss of biodiversity, second only to habitat destruction (Sala et al., 2000).

In aquatic environments, the introduction of exotic species is facilitated by the water flow, and has been responsible for changes in trophic relationships, density and species distribution. In the lake district of Middle Doce River, located at the Steel Valley in Minas Gerais, most lakes are inserted in a conservation unit (Rio Doce State Park- PERD), however the presence of exotic species was registered for fish (Godinho and Formagio, 1992; Latini and Petrere, 2004) and for the benthic macroinvertebrate community (De Marco Jr., 1999). The present paper registers the first record of exotic species for the zooplankton community.

Data for the zooplankton species were obtained from the Program for Long-Term Ecological Research (LTER / UFMG - site 4), which 
monitored the plankton biodiversity in seven lakes (Carioca, Dom Helvécio, Gambazinho, Jacaré, Águas Claras, Palmeirinha, Amarela) during eight years (2000-2007) (Figure 1).

Two zooplankton species were considered exotic to the region of Middle River Doce: Kellicottia bostoniensis (Rotifera) and Mesocyclops ogunnus (Copepoda).

Kellicottia bostoniensis (Figure 2) is an indigmous rotifer in North America (Edmondson, 1959). However, it has been widely sampled in aquatic environments of Europe (Arnemo et al., 1968;
Balvay, 1994 among others) and South America tolerating a wide variation in environmental conditions (Arnemo et al., 1968).

In Brazil, the first record of the species $K$. bostoniensis occurred at the Segredo Reservoir located at River Iguaçu, PR (Lopes et al., 1997). Kellicotia bostoniensis was identified in freshwater habitats in the Upper Tietê River hydrographic basin (São Paulo State) (Lucinda et al., 2004) and, in Minas Gerais State, this rotifer was recorded at Furnas (river Rio Grande) (Landa et al., 2002), Nova Ponte, Miranda (Souza, 2004) and Capim Branco I

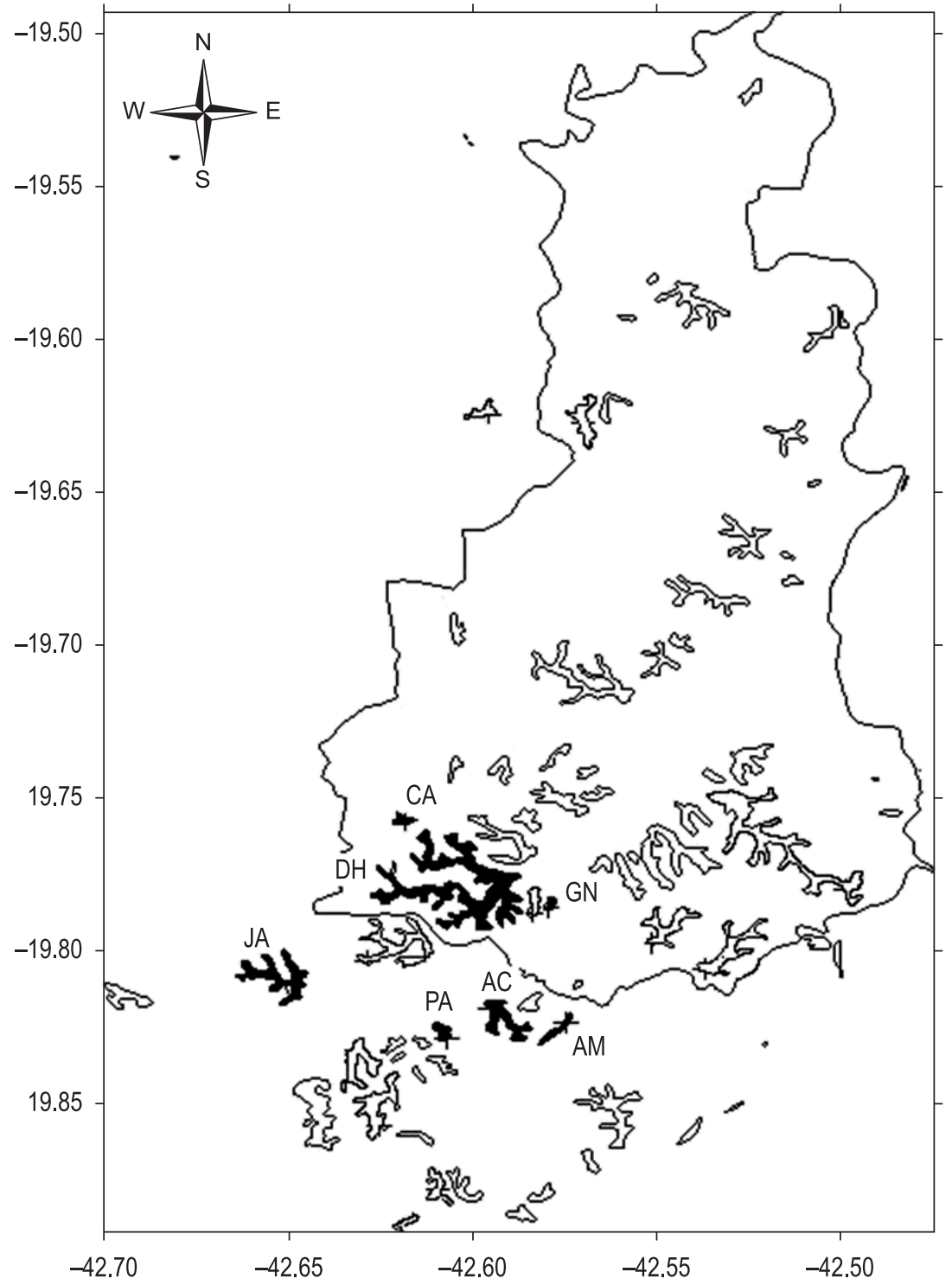

Figure 1. Map of the seven lakes studied in the Médio Rio Doce. The contour line delimits in the Parque Estadual do Rio Doce (Médio Rio Doce), containing in its interior Lakes Carioca (CA - $19^{\circ} 45^{\prime} 26,0$ ' S and 042 $37^{\prime}$ 06,2' 'W) Gambazinho (GN - $19^{\circ} 47^{\prime} 07,7^{\prime \prime} \mathrm{S}$ and $042^{\circ} 34^{\prime} 45,5^{\prime} \mathrm{W}$ ) and Dom Helvécio (DH - 19 46' 55,7” S and $\left.042^{\circ} 35^{\prime} 28,9^{\prime \prime} \mathrm{W}\right)$, and in its surrounding Lakes Jacaré (JA - $19^{\circ} 48^{\prime} 37,8^{\prime \prime} \mathrm{S}$ and $042^{\circ} 38^{\prime} 57,0^{\prime \prime}$ W), Palmeirinha (PA - $19^{\circ} 49^{\prime} 41,8^{\prime \prime} \mathrm{S}$ and $042^{\circ} 36^{\prime} 25,4^{\prime \prime} \mathrm{W}$ ), Águas Claras (AC - $19^{\circ} 49^{\prime} 06,9^{\prime \prime} \mathrm{S}$ and $042^{\circ} 35^{\prime} 42,5^{\prime \prime} \mathrm{W}$ ) and Amarela (AM - 19 49' 23,1" S and $\left.042^{\circ} 34^{\prime} 28,7^{\prime \prime} \mathrm{W}\right)$. 
(Valadares, 2007) (River Araguari) reservoirs and at Lagoa do Nado, BH (Bezerra-Neto et al., 2004). The high potential for colonization of this species is a reflection of good dispersibility and high ecological plasticity, being able to efficiently explore environments with different trophic states (Bezerra-Neto et al., 2004).

Kellicotia bostoniensis was found at low densities in the lakes Carioca, Águas Claras and Jacaré. In Lake Jacaré its highest density was 117 org. $\mathrm{m}^{-3}$ in March 2005. This species was sampled also in July and November of that year. This lake is located outside the boundaries of PERD, and is used as a fishing club. In Lake Águas Claras, also located outside the park boundaries, this species was sampled only in January 2005, with a total

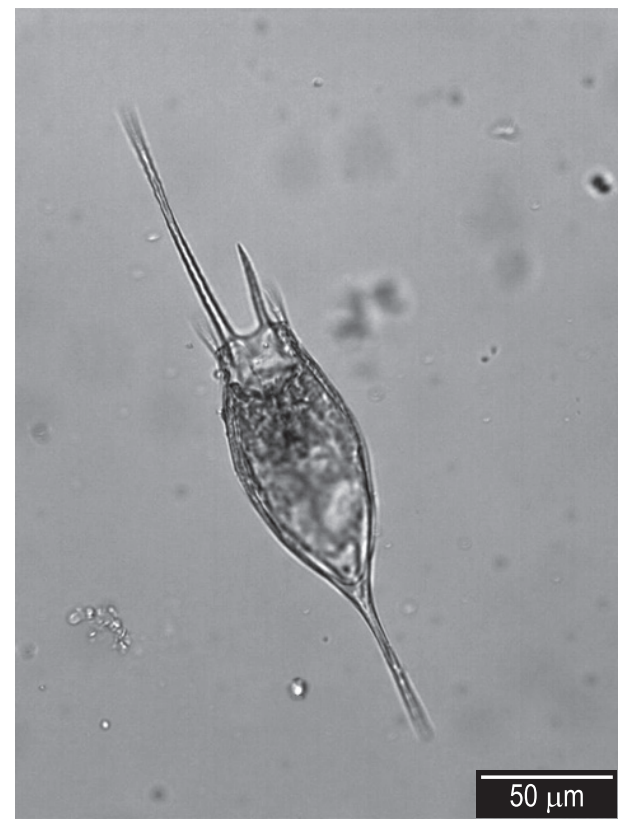

Figure 2. Kellicottia bostoniensis.

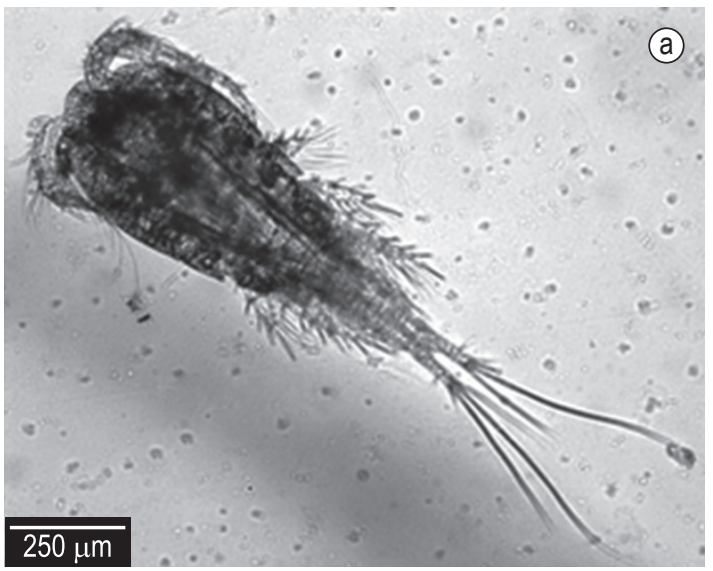

of 56 org. $\mathrm{m}^{-3}$. In Lake Carioca $K$. bostoniensis was sampled in May (66 org. $\left.\mathrm{m}^{-3}\right)$, June (12 org. $\left.\mathrm{m}^{-3}\right)$, July $\left(29\right.$ org. $\left.\mathrm{m}^{-3}\right)$, October (33 org. $\left.\mathrm{m}^{-3}\right)$, November $\left(83\right.$ org. $\left.\mathrm{m}^{-3}\right) 2005$ and January 2006 (8 org. $\left.\mathrm{m}^{-3}\right)$ (Figure 3). Lake Carioca is located within the park and is not open to the public.

Mesocyclops ogunnus (Figure 4) is a Copepoda Cyclopoida, with an African-Asian origin, first recorded in the Americas in 1993, at Furnas reservoir (Reid and Pinto-Coelho, 1994). Recently, the species was sampled in 15 reservoirs of São Paulo (Silva, 2003) and in the floodplain of the Upper Paraná (Lansac-Toha et al., 2002). According to Silva (2003) M. ogunnus is a typical species of limnetic region occurring in great abundance at the reservoirs of Tietê River Basin. MatsumuraTundisi and Silva (2002) clarify the identification

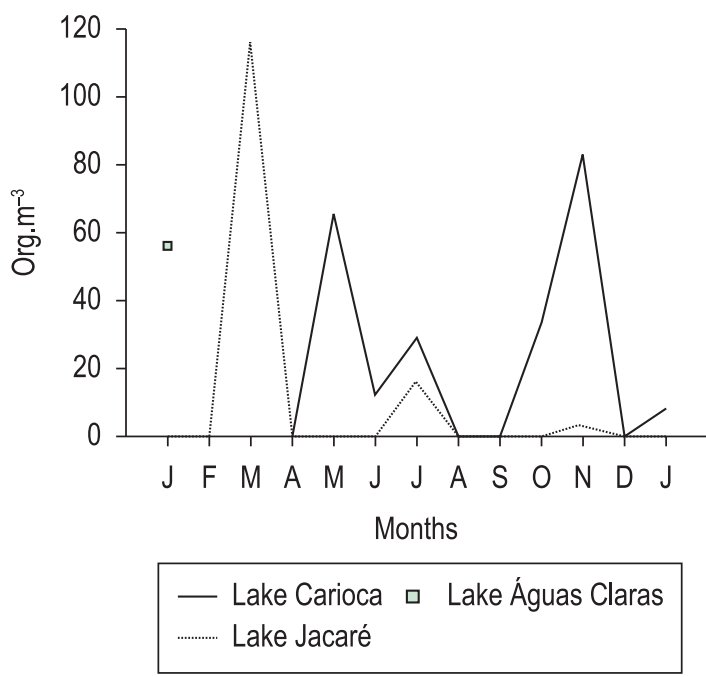

Figure 3. Population fluctuation of Kellicottia bostoniensis (org. $\mathrm{m}^{-3}$ ) in Lakes Carioca, Águas Claras and Jacaré from January 2005 to January 2006.

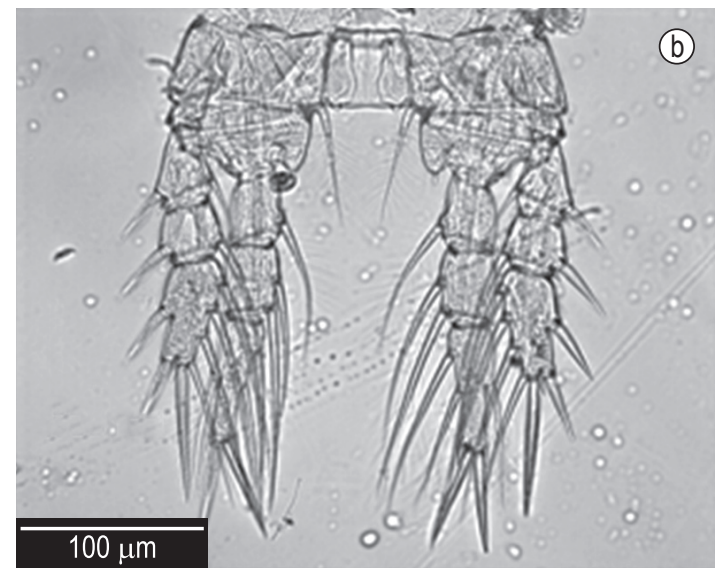

Figure 4. a) Mesocyclops ogunnus female; and b) the fourth paw detail. 
of $M$. ogunnus that occured in several reservoirs in the State of São Paulo and was previously identified as $M$. kieferi. These two species are closely related and have very similar characteristic.

In the lakes of Middle River Doce, this species was recorded with low densities (400 org. $\mathrm{m}^{-3}$, representing $0.34 \%$ of total microcrustaceans) in the littoral zone of Lake Dom Helvécio, considered an oligo-mesotrophic environment (Peixoto, 2007).

These zooplankton species may have been introduced in these environments by natural phenomena such as animal transport and wind action (Lopes et al., 1997, Jenkins and Underwood, 1998) or by human action (Reid and Pinto-Coelho, 1994). The production of dormant forms (resting eggs, for example) is a strategy widely documented for the zooplankton (Fryer 1996, Brendonck and De Meester, 2003, Gyllström and Lars-Anders, 2004) and ensures the persistence of the population in an environment that has become inhospitable to organisms. The eggs are extremely resistant to drought (Fryer, 1996), and may remain viable for long periods in fishing nets, survey equipment, boats, clothes and animals, increasing the chances of population recovery and dispersal / invasion of other aquatic environments.

It is likely that the introduction of these species is human related to the introduction of fish in lakes of the Middle River Doce, since the presence of $K$. bostoniensis and $M$. ogunnus was only observed in lakes where exotic fish species were recorded, including Lake Jacaré. In this lake there is a fishing club, a probable source of species dispersal to other lakes in the region.

Invertebrates invasions, particularly in the plankton realm, were, for a long time, rarely considered or reported, mainly due the difficulty of identifying the fact.

The monitoring of the invasion process is necessary to evaluate the possible impacts on the zooplankton community structure in lakes of the Middle River Doce.

\section{Acknowledgements}

We thank the members of the Laboratory of Ecology of Zooplankton (ICB / UFMG) for the session data. We also thank the National Council of Scientific and Technological Development (CNPq), which funded the project program Long Term Ecological Research (LTER).

\section{References}

ARNEMO, R., BERZINS, B., GRONBERG, B. and MELLGREN, I., 1968. The dispersal in Swedish waters of Kellicottia bostoniensis (Rousselet) (Rotatoria). Oikos, vol. 19, p. 351-358.

BALVAY, G., 1994. First record of the rotifer Kellicottia bostoniensis (Rousselet, 1908) in France. Journal of Plankton Research, vol. 16, no. 8, p. 1071-1074.

BEZERRA-NETO, JF., AGUILA, LA., LANDA, GG. And PINTO-COELHO, RM., 2004. The exotic rotifers Kellicotia bostoniensis (Rousselet,1908) (Rotifera:Brachionidae) in the zooplankton community in the tropical reservoir. Lundiana, vol. 5, no. 2, p. 151-153.

BRENDONCK, L. and DE MEESTER, L., 2003. Egg banks in freshwater zooplankton: evolutionary and ecological archives in the sediment. Hydrobiologia, vol. 491, p. 65-84.

DE MARCO JUNIOR, P., 1999. Invasion by the introduced aquatic snail Melanoides tuberculata (Müller, 1774) (Gastropoda: Prosobranchia: Thiaridae) of the Rio Doce State Park, Minas Gerais, Brazil. Studies of Neotropical Fauna and Environment, vol. 34, p. 186-189.

EDMONDSON, WT., 1959. Freshwater biology. New York, Jonh Wiley.

FRYER, G., 1996. Diapause, a potent force in the evolution of freshwater crustaceans. Hydrobiologia, vol. 320, p. 1-14.

GODINHO AL. and FORMAGIO, PS., 1992. Efeitos da introdução de Cichla ocellaris e Pygocentrus sp. sobre a comunidade de peixes da lagoa Dom Helvécio. In: Anais do 10 Encontro Anual de Aquicultura de Minas Gerais, 10. 1992. p. 93-102.

GYLLSTRÖM, M. and LARS-ANDERS, H., 2004. Dormancy in freshwater zooplankton: induction, termination and the importance of benthic-pelagic coupling. Aquatic Science, vol. 66, p. 274-295.

JENKINS, D. G. and UNDERWOOD, M. O., 1998. Zooplankton may not disperse readily in wind, rain, or waterfowl. Hydrobiologia, vol. 387, p. 15-21.

LANDA, GG., AGUILA, LR. and PINTO-COELHO, RM., 2002. Spatial and temporal distribution of Kellicottia bostoniensis (Rousselet, 1908) (Rotifera) in a large tropical reservoir (Furnas Reservoir), state of Minas Gerais, Brazil. Acta Scienciarum, vol. 24, no. 2, p. 313-319.

LANSAC-TÔHA, FA., VELHO, LFM., HIGUTI, J. and TAKAHASHI, EM., 2002. Cyclopidae (Crustacea, Copepoda) from the upper Paraná River floodplain, Brazil. Brazilian Journal of Biology, 2002, vol. 62, no. 1, p. 125-133.

LATINI, AO. and PETRERE, M., 2004. Reduction of a native fish fauna by alien species: an example 
from Brazilian freshwater tropical lakes. Fisheries Management and Ecology, vol. 11, p. 71-79.

LOPES, RM., LANSAC-TÔHA, FA., VALE, R. and SERAFIM, JRM., 1997. Comunidade zooplanctônica do reservatório de Segredo. In AGOSTINHO, AA. And GOMES, LC. Reservatório de segredo: bases ecológicas para o manejo. Maringá: EDUEM.

LUCINDA, I., MORENO, IH., MELÃO, MGG. and MATSUMURA-TUNDISI, T., 2004. Rotifers in freshwater habitats in the upper Tietê River Basin, São Paulo State, Brazil. Acta Limnologica Brasiliensia, vol. 16, no. 3, p. 203-224.

MATSUMURA-TUNDISI, T. and SILVA, WM., 2002. Occurrence of Mesocyclops ogunnus Onabamiro, 1957 (Copepoda Cyclopoida) in water bodies of São Paulo State, identified as Mesocyclops kieferi Van de Velde, 1984. Brazilian Journal of Biology, vol. 62, no. 4A, p. 615-620.

MOONEY, HA. and HOBBS, RJ., 2000. Invasive species in a changing world. Washington, DC Island Press.

PEIXOTO, RS., 2007. Estudos ecológicos sobre as assembléias de microcrustáceos (Copepoda e Cladocera) na região litorânea do lago Dom Helvécio, Minas Gerais, Brasil. Universidade Federal de Minas Gerais - UFMG. [Dissertação de mestrado].

REID, JW. and PINTO-COELHO, RM., 1994. An Afro-Asian continental copepod, Mesocyclops ogunnus found in Brazil; with a new key to the species of Mesocyclops in South America and a review of international introductions of copepods. Limnologica, vol. 28 , no. 4 , p. 359-368.
RICCIARDI, A. and MACLSSAC, HJ., 2000. Recent mass invasion of the North-American Great Lakes by Ponto-Caspian species. Trends in Ecology and Evolution, vol. 19, p. 18-24.

SALA, OE., CHAPIN III., FS., ARMESTO, JJ., BERLOW, E., BLOOMFIELD, J., DIRZO, R., HUBER-SANWALD, E., HUENNEKE, LF, JACKSON, RB., KINZIG, A., LEEMANS, R., LODGE, DM., MOONEY, HA., OESTERHELD, M., POFF, NL., SYKES, MT., WALKER, BH., WALKER, M. and WALL, DH., 2000. Global biodiversity scenarios for the year 2100. Science, vol. 287, p. $1770-1774$.

SILVA, WM., 2003. Diversidade de Cyclopoida (Crustacea, Copepoda) de água doce do estado de São Paulo: taxonomia, ecologia e genética. São Carlos, UFSCAR.154 p. [Tese de doutorado].

SOUZA, MBG., 2004. Qualidade das águas e a comunidade do zooplâncton: bacia do rio Araguari. Belo Horizonte: Escola de Engenharia, Universidade Federal de Minas Gerais.

VALADARES, CF., 2007. Alteraçôes nas características limnológicas e na comunidade zooplanctônica do rio Araguari (MG) em função das obras hidráulicas de Capim Branco I. Universidade Federal de Minas Gerais - UFMG. [Dissertação de mestrado].

WILLIAMSON, M., 1996. Biological invasions. London: Chapman \& Hall.

Received: 07 July 2010 Accepted: 01 February 2011 